\title{
Enhanced decolourization of congo red dye under submerged fermentation (SMF) process by newly isolated Bacillus subtilis SPR $_{42}$
}

\author{
Baljeet Singh Saharan* and Poonam Ranga \\ Department of Microbiology, Kurukshetra University, Kurukshetra-136 119 (Haryana), INDIA \\ *Corresponding author. E-mail: baljeet@daad-alumni.de
}

\begin{abstract}
Studies were carried out on the decolourization of textile azo dye using newly isolated aerobic bacterial culture. Among the 58 strains of aerobic bacteria isolated from soil contaminated with textile industry (Shivalik polymer Ltd. Faridabad) effluent, three showed remarkable ability in decolourizing the widely utilized azo dye (Congo Red). These strains also readily grew in and decolourized the high concentrations of dye (100 mg $\left.\mathrm{L}^{-1}\right)$. The aerobic bacterial isolate $\mathrm{SPR}_{42}$, was able to decolourize the Congo Red dye at a concentration of $100 \mathrm{mgL}^{-1}$ upto $94 \%$ within $24 \mathrm{hrs}$ at static conditions. The temperature and $\mathrm{pH}$ for optimum growth and activity of the isolate were reported as $37{ }^{\circ} \mathrm{C}$ and 8.5, respectively. The colorless bacterial biomass after decolourization suggested that decolourization was due to biodegradation, rather than inactive surface adsorption. Phenotypic characterization and phylogenetic analysis based on 16S rDNA sequence comparisons indicate that the strain $\mathrm{SPR}_{42}$ identified as Bacillus subtilis. This isolate can be a potential strain for biological treatment of effluents of TPI (Textile Processing Industry).
\end{abstract}

Keywords: Biodegradation, Decolourization, Textile dye, Textile effluent, Congo red dye

\section{INTRODUCTION}

Explosion of population coupled with industrial revolution results in pollution of water, air and soil. The discharge of pollutants from various industries poses threat to the biodiversity of earth (Muthezhilan et al., 2008). The textile industry consumes large quantities of water and produces huge volume of waste water from different steps in the dyeing and finishing process (Babu et al., 2007). The dyes present in textile effluent impart persistent colour to the receiving streams and interfere with photosynthesis of the phytoplankton (Cunningham et al., 2001). Synthetic dyes have a wide application in food, textile, leather, cosmetics and paper industries due to their ease of production, fastness and variety in colour (Adedayo et al., 2004). Azo dyes are largest and most versatile class of dyes and are widely used in textile industries. More than 2000 structurally different azo dyes are currently in use (Kumar et al., 2007). The annual world production of azo dyes is estimated to be around one million tons (Stolz, 2001; Pandey et al., 2007). In India, an average mill discharges is about 1.5 million litres of effluent per day, which leads to cause choronic and acute toxicity (Sandhya et al., 2005 and Arami et al., 2006). Azo dyes are xenobiotic compounds, characterized by one or more azo groups (-N=N-) (Selvam et al., 2003). Due to their chemical structures, dyes are resistant to fading on exposure to light and water (Robinson et al., 2001). Dyes are toxic, highly persistent and ubiquitously distributed in the environment (Pearce et al., 2003; Maguire, 1992;
Zollinger, 1991). Removal of these dyes from effluent is necessary not only for aesthetic reasons, but also because many azo dyes and their breakdown products (aromatic amines) are toxic and mutagenic (Weisburger, 2002). But because of the high cost and disposal problems, most of chemical and physical methods for treating dye waste water were not widely applied in the textile industries (Mazmanci and Unyayar, 2005). In this situation it is mandatory to treat such wastewater prior to their discharge. Among various physico-chemical processes, biological methods are considered to be a promising one (Crini, 2006; Kumar et al., 2006; Silver et al., 2006; Batzias and Sidiras, 2007). Therefore, the objective of this study was to focus our attention on the isolation of efficient dye-decolourizing bacteria from contaminated sites of an industrial estate.

\section{MATERIALS AND METHODS}

Chemicals: All the chemicals used during the present investigation were of analytical (AR) grade. The Congo Red (Azo dye) used in this study was obtained from textile industry, Faridabad.

Medium: Two types of media were used in this study. Nutrient Agar media and Mineral Salt media $\left(\mathrm{K}_{2} \mathrm{HPO}_{4}-\right.$ $6.3, \mathrm{KH}_{2} \mathrm{PO}_{4}-1.8, \mathrm{NH}_{4} \mathrm{NO}_{3}-1.0, \mathrm{MgSO}_{4} .7 \mathrm{H}_{2} \mathrm{O}-0.006$, Yeast extract- $5.0 \mathrm{gL}^{-1}$ ).

Isolation of bacterial strains: Dye degrading bacteria were isolated from soil samples, which were collected from various dye contaminated sites (effluent treatment plant and solid waste dumping site) of textile industry. 


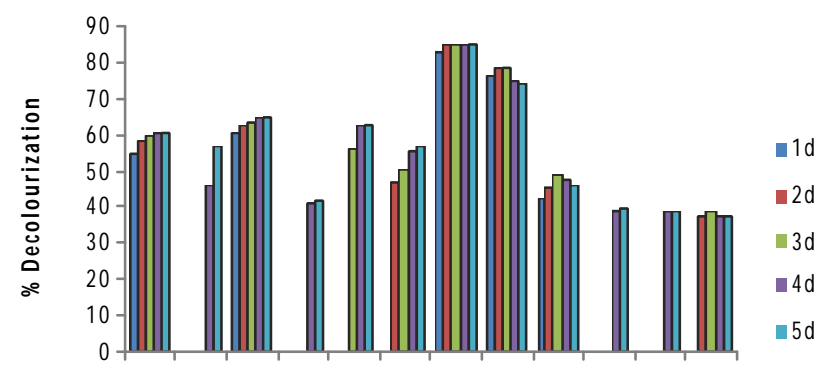

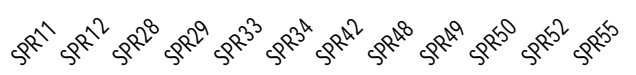

Isolates

Fig. 1.Decolourization shown by selected isolates during secondaryscreening.

The isolation was done in laboratory. For the isolation of dye degrading bacteria, soil samples $(1.0 \mathrm{~g})$ were suspended in sterile water blanks aseptically and various dilutions were made accordingly. About $1.0 \mathrm{ml}$ of higher dilutions $\left(10^{-5}\right.$ to $\left.10^{-7}\right)$ was spreaded on Nutrient agar plates containing dye and then incubated at $37^{\circ} \mathrm{C}$ for 5 days. Isolated colonies were picked up and further streaked on Nutrient agar plates. Purification and initial characterization of isolates were done by repeated streak plate method and staining methods, respectively. Further the cultures were confirmed by molecular characterization. Screening of isolates having decolourization activity: Inoculum preparation was done by aerobically growing the cells at $37^{\circ} \mathrm{C}$ for $24 \mathrm{~h}$ in mineral media at $\mathrm{pH}-7.2$. For screening of isolates mineral media having concentration of dye $100 \mathrm{mgL}^{-1}$ was inoculated with $24 \mathrm{~h}$ old precultured cells $1.0 \%(\mathrm{v} / \mathrm{v})$. The decolourization of dye was monitored at every $24 \mathrm{~h}$ intervals. Primary screening was done only on visibility basis i.e. change in colour of media containing respective dye.

In secondary screening, percent decolourization was measured as decrease in optical density using spectrophotometer (Systronics PC based double beem spectrophotometer 2202).

Effect of incubation temperature: The effect of incubation temperature on the decolourization was studied by incubating the mineral media containing dye

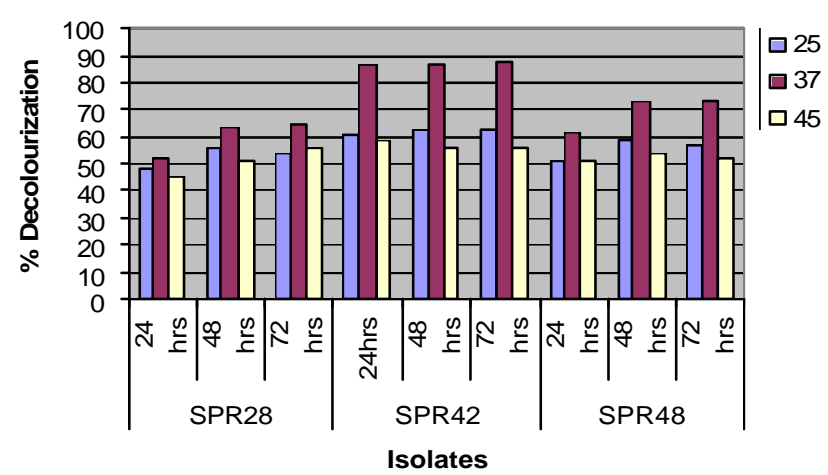

Fig. 2. \% Decolourization of selected isolates at different temperatures.
$100 \mathrm{mgL}^{-1}$ under a range of temperatures $\left(15^{\circ} \mathrm{C}, 25^{\circ} \mathrm{C}, 37\right.$ ${ }^{\circ} \mathrm{C}, 45^{\circ} \mathrm{C}, 55^{\circ} \mathrm{C}$ and $65^{\circ} \mathrm{C}$ ) at $\mathrm{pH} 7.0$.

Effect of pH: Colonies of an overnight grown culture were used to inoculate the mineral media containing dye 100 $\mathrm{mgL}^{-1}$. The $\mathrm{pH}$ of the medium was adjusted 5.0, 6.0, 7.0, 7.5, 8.0, 8.5, 9.0 and at temperature $37^{\circ} \mathrm{C}$.

\section{RESULTS AND DISCUSSION}

Collection of soil samples: Collection of soil samples was done from various sites of textile industry like effluent treatment plant and their solid waste dumping sites. Total 58 different isolates were obtained from the soil samples. These isolates were numbered from 1 to 58 on morphological basis.

Primary screening: From total 58 isolated bacteria only 12 bacteria have the capability of showing visible decolourization of Congo Red within 5 days. Then these 12 selected bacteria were further used in secondary screening.

Secondary screening: Among 12 chosen isolates only three isolates namely $\mathrm{SPR}_{28}, \mathrm{SPR}_{42}$ and $\mathrm{SPR}_{48}$ showed decolourization up to $60 \%$ with in three days. The rate of decolourization was determined by Decolourization assay. These 3 selected isolates were further used for optimization of cultural conditions (Fig. 1).

Effect of temperature: The isolates $\mathrm{SPR}_{28}$ and $\mathrm{SPR}_{48}$ showed maximum decolourization up to $63 \%$ and $72 \%$, respectively within $48 \mathrm{~h}$ at temperature $37{ }^{\circ} \mathrm{C}$. Among these, the maximum decolourization shown by $\mathrm{SPR}_{42}$ was up to $86 \%$ within $24 \mathrm{~h}$. Whereas these three selected isolates could not show decolourization at temperatures: $15{ }^{\circ} \mathrm{C}, 55^{\circ} \mathrm{C}$ and $65^{\circ} \mathrm{C}$. It was noticed that with an increase in temperature from 25 to $40^{\circ} \mathrm{C}$ the decolourization rate was increased and a further increase in temperature up to $50{ }^{\circ} \mathrm{C}$ drastically affected decolourization activity of isolates (Fig. 2).

Similar results were reported by Moosvi et al. in 2005. Decolourization of Acid Red B Dye by the three strains was investigated over a range of $25-40^{\circ} \mathrm{C}$. Different most favorable temperatures $35^{\circ} \mathrm{C}$ for $R$. sphaeroides AS1.1737, $30{ }^{\circ} \mathrm{C}$ for $R$. palustris AS1.2352 and $40^{\circ} \mathrm{C}$ for E. coli $\mathrm{YB}$, were observed (Liu et al., 2007).

Effect of pH: As obvious from Fig. 3, all three isolates showed no decolourization at $\mathrm{pH} 5.0$ and 6.0. For all the 3 isolates the suitable $\mathrm{pH}$ was in the range of 7.0 to 9.0 with 8.5 as optimum. The isolates $\mathrm{SPR}_{28}$ and $\mathrm{SPR}_{48}$ showed maximum decolourization $75 \%$ and $90 \%$, respectively within $48 \mathrm{~h}$ at $\mathrm{pH}-8.5$. The maximum decolourization shown by $\mathrm{SPR}_{42}$ was $94 \%$ with in $24 \mathrm{~h}$ at $\mathrm{pH}-8.5$.

The literature also supports such studies. According to Guang-fei Liu (2007), the most favorable $\mathrm{pH}$ for $R$. sphaeroides AS1.1737 and R. palustris AS1.2352 was around 6.0, with decolorization rates of 322.05 and 288.06 mg dye g cell- $1 \mathrm{~h}-1$, respectively, indicating that neutral 


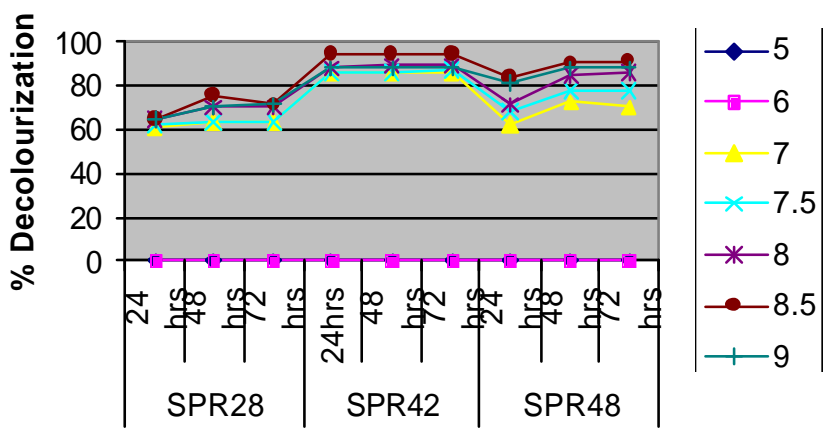

Isolates

Fig. 3.\% Decolourization shown by selected isolates at different pH.

and slightly acidic $\mathrm{pH}$ values (6.0-7.0) were favorable for Acid Red B decolorization by ESP cultures of PSB strains. However, the optimal $\mathrm{pH}$ for $E$. coli $\mathrm{YB}$ was around 8.0, with a specific decolorization rate of $44.12 \mathrm{mg}$ dye $\mathrm{g}$ cell- $1 \mathrm{~h}-1$. The study concluded that aerobic bacteria namely $\mathrm{SRR}_{42}$, $\mathrm{SPR}_{28}$ and $\mathrm{SPR}_{48}$ have well adapted in the effluent enriched soil. The isolate $\mathrm{SPR}_{42}$ (Bacillus subtilis) showed best decolourization activity $(94 \%)$ at $37^{\circ} \mathrm{C}(\mathrm{pH} 8.5)$. The findings of the study can be used to develop economically feasible way to better bioremediate the effluents in order to avoid the possible adverse effect of discharged effluents containing mutagenic and carcinogenic dyes on human beings and biota.

\section{ACKNOWLEDGEMENTS}

The University Grant Commission (UGC) is highly acknowledged for providing financial support to $\mathrm{PR}$ in the form of JRF [File No. F14-2(SC)/2007(SA-III)].

\section{REFERENCES}

Adedayo, O., Javadpour, S., Taylor, C., Anderson, W.A. and Moo-Young, M. (2004). Decolourization and detoxification of methyl red by aerobic bacteria from a wastewater treatment plant. World Journal of Microbiology and Biotechnology, 20:545-550.

Arami, M., Limaee, N.Y., Mahmoodi, N.M. and Tabrizi, N.S. (2006). Equilibrium and kinetics studies for the adsorption of direct and acid dyes from aqueous solution by soy meal hull. Journal of Hazardous Materials, 135: 171-179.

Babu, B.R., Parande, A.K., Raghu, S. and Kumar, T.P. (2007). Cotton textile processing: Waste generation and effluent treatment. Journal of Cotton Science, 11: 141-153.

Batzias, F.A. and Sidiras, D.K. (2007). Dye adsorption by prehydrolysed beech sawdust in batch and fixed-bed systems. Bioresource Technology, 98: 1208-1217.

Crini, G. (2006). Non-conventional low cost adsorbents for dye removal: a review. Bioresource Technology, 97: 10611085.

Cunningham, W.P. and Siago, B.W. (2001). Environmental Science. New York: Global Concern, McGraw Hill. 267-269.
Kumar, S.S., Kalaamani. P., Porkodi, K., Varadajan, P.R. and Subburaan, C.V. (2006). Adsorption of dissolved reactive red dye from aqueous phase on to activated carbon prepared from agricultural waste. Bioresource Technology, 97: 1618-1625.

Kumar, V.M.H., Vaishampayan, P.A., Shouche, Y.S. and Karegoudar, T.B. (2007). Decolourization of naphthalenecontaining sulfonated azo dyes by Kerstersia sp strain VKY 1. Enzyme and Microbial Technology, 40: 204-211.

Liu, G Zhou, J.T. and Qu, Y.Y. (2007). Decolorization of sulfonated azo dyes with two photosynthetic bacterial strains and a genetically engineered Escherichia coli strain. World Journal of Microbiology and Biotechnology, 23:931-937.

Maguire, R.J. (1992). Occurrence and persistence of dyes in a Canadian river. Water Science Technology, 25: 265-270.

Mazmanci, M.A. and Unyayar, A. (2005). Decolourization of reactive black 5 by Funalia trogii immobilized on Luffa cylindrica sponge. Process Biochemistry, 40:337-342.

Moosvi, S. Keharia, H. and Madamwar, D. (2005). Decolorization of textile dye Reactive violet 5 by a newly isolated bacterial consortium RVM 11.1. World Journal of Microbiology and Biotechnology, 21:667-672.

Muthezhilan, R., Yogananth, N., Vidhya, S. and Jayalakshmki, S. (2008). Dye degrading mycoflora from industrial effluents. Research Journal of Microbiology, 3: 204-208.

Pandey, A., Singh, P. and Iyengar, L. (2007). Bacterial decolorization and degradation of azo dyes.International Journal of Biodeterioration and Biodegradation, 59:73-84.

Pearce, C.I., Lloyd, J.R. and Guthrie, J.T. (2003). The removal of colour from textile wastewater using whole bacterial cells: a review. Dyes and Pigments, 58: 179-196.

Robinson, T., Mcmullan, G., Marchant, R. and Nigam, P. (2001). Remediation of dyes in textile effluents: a critical review on current treatment technologies with a proposed alternative. Bioresource Technology, 77: 247-255.

Sandhya, S., Padmavathy, S., Swaminathan, K., Subrahmanyam, Y.V. and Kaul, S.N. (2005). Microaerophilic-aerobic sequential batch reactor for treatment of azo dyes containing simulated wastewater. Process Biochemistry, 40: 885-890.

Selvam, K., Swaminathan, K. and Keo-Sangh, C. (2003). Microbial decolorization of azo dyes and dye industry effluent by Fomes lividus. World Journal of Microbiology and Biotechnology, 19:591-593.

Silver, C.G., Wang, W. and Faria, J.L. (2006). Photocatalytic and photochemical degradation of mono -, di - and tri-azo dyes in aqueous solution under UV irradiation. Journal of Photochemistry and Photobiology, 181:314-324.

Stolz, A. (2001). Basic and applied aspects in the microbial degradation of azo dyes. Applied Microbiology and Biotechnology, 56: 69-80.

Weisburger, J.H. (2002). Comments on the history and importance of aromatic and heterocyclic amines in public health. Mutation Research, 506-5079-20.

Zollinger, H. (1991). Color chemistry: syntheses, properties and applications of organic dyes and pigments, $2^{\text {nd }}$ edn. (Wiley, New York) 92-102. 